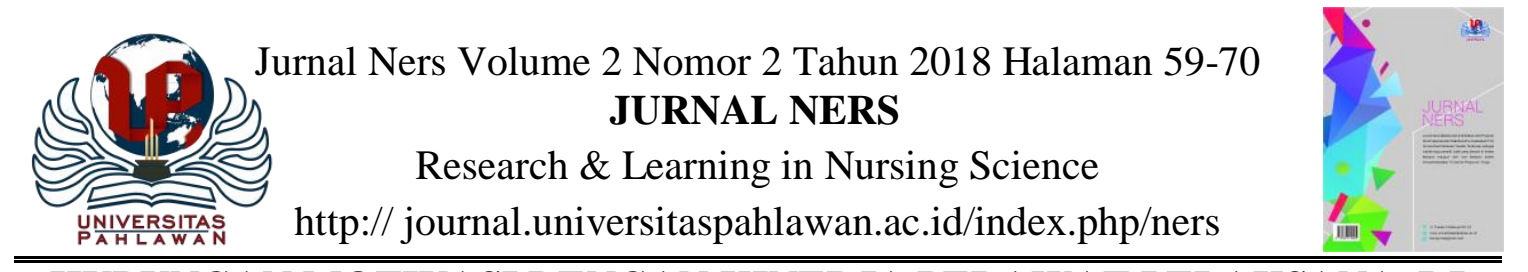

\title{
HUBUNGAN MOTIVASI DENGAN KINERJA PERAWAT PELAKSANA DI UPTD KESEHATAN TAPUNG KAB. KAMPAR \\ TAHUN 2018
}

\author{
Nany Librianty \\ Dosen Program Studi Sarjana Keperawatan \\ Universitas Pahlawan Tuanku Tambusai
}

\begin{abstract}
ABSTRAK
Perawat merupakan sumber keberhasilan pembangunan kesehatan ditingkat puskesmas. Hal ini didukung oleh kinerja perawat. Kinerja perawat didukung oleh motivasi yang baik. Motivasi yang baik dapat mendorong perawat agar senang bekerja dan meningkatkan rasa tanggung jawab untuk melakukan pekerjaan dengan lebih baik. Untuk itu motivasi mempunyai peran yang penting dalam peningkatan kinerja perawat. Penelitian ini bertujuan untuk mengetahui hubungan motivasi dengan kinerja perawat pelaksana di UPTD kesehatan Tapung Kab. Kampar tahun 2018. Penelitian ini dilakukan pada perawat di UPTD kesehatan Tapung dengan jumlah subyek penelitian sebanyak 30 orang. Instrumen pengumpulan data yang digunakan adalah kuesioner. Terdapat 2 kuesioner yaitu kuesioner tentang motivasi kerja sebanyak 10 soal dan kuesioner kinerja perawat sebanyak 10 kuesioner. Desain penelitian ini menggunakan desain deskriptif kolerasi dengan pendekatan cross sectional. Tehnik pengambilan sampel menggunakan total sampling. Analisis data dilakukan dengan tek nik uji korelasi chi square. Distribusi ferekuensi berdasarkan usia, dari 30 responden yang paling banyak berusia 25-35 tahun sebanyak 19 orang. Dari tabel distribusi ferekuensi responden berdasarkan pendidikan didapatkan hasil yang paling banyak berpendidikan D3 keperawatan sebanyak 19 orang.distribusi ferekuensi berdasarkan jenis kelamin yang paling banyak berjenis kelamin perempuan sebanyak 18 orang, darihasil uji statistik diperoleh perawat yang motivasi termotivasi dengan kinerja baik sebanyak $(77.8 \%)$, dan perawat yang mempunyai motivasi tidak termotivasi dengan kinerja baik sebanyak $(25.0 \%)$ nilai $\mathrm{p}$ value $0,004<0,05$ maka dapat disimpulkan terdapat hubungan antara motivasi dengan kinerja perawat pelaksana rawat inap di UPTD Kesehatan Tapung Kab. Kampar hasil analisis diperoleh nilai POR sebesar 10,50 artinya tingkat motivasi perawat termotivasi beresiko 10,50 kali, berpeluang untuk mempunyai kinerja kurang baik. Diharapkan kepada perawat untuk dapat meningkatkan kinerja perawat dalam memberikan pelayanan keperawatan langsung kepada pasien yang dirawat. Hal ini menunjukkan bahwa ada hubungan yang segnifikan antara motivasi dengan kinerja perawat pelaksana di UPTD kesehatan Tapung tahun 2018.
\end{abstract}

\section{Kata kunci : motivasi, kinerja perawat}




\section{PENDAHULUAN}

Penurunan kinerja perawat pelaksana mengakibatkan mutu asuhan keperawatan pada pasien dan keluarganya yang buruk sehingga akan mempengaruhi citra pelayanan dan kepercayaan masyarakat terhadap puskesmas menjadi menurun. Pasolong, 2008 menjelaskan bahwa kinerja seseorang ditentukan oleh kemampuan untuk melaksanakan pekerjaan.

Banyaknya lowongan yang dibuka bagi tenaga kesehatan dinegara maju merupakan pertanda bahwa pasar potensi terbuka lebar. Dan laporan WHO ( 2006 ) menyatakan bahwa densitas tenaga kesehatan berhubungan kuat dengan probabilitas keselamatan hidup. Baik keselamatan hidup bayi, anak, maupun ibu. Dan kinerja perawat ini sangat dipengaruhi oleh motivasi kerja, upah atau gaji, lingkungan kerja, dan kesempatan berprestasi dan pendidikan

Pada abad ke 21 ini tantangan SDM semakin komplek selain persoalan klasik mengenai jumlah, jenis, mutu serta maldistribusi, persoalan kontektual seperti desentralisasi dan migrasi juga perlu dikaji, meskipun tergolong klasik namun berbagai pendekatan masih belum mampu untuk mencegah persoalan ini. Tantangan ini tidak hanya menjadi domain domestik, tetapi juga menjadi persoalan permasalahan di negara maju.

Puskesmas sebagai salah satu wadah pelayanan kesehatan yang dikembangkan melalui pemenuhan kesehatan seperti kesehatan dir awat inap, Rawat jalan, dan non medik ( depkes, 1998 ). Bagi pasien pemakai jasa pelayanan kesehatan, mutu pelayanan kesehatan lebih terikat pada dimensi ketanggapan petugas memenuhi kebutuhan pasien, kelancaran komunikasi petugas dengan pasien, kepribadian serta keramahan melayani dan cepat sembuh dari penyakitnya

Perawat di puskesmas rawat inap merupakan tumpuan dari semua kegiatan yang ada karena perawat merupakan sumber keberhasilan pembangunan kesehatan di tingkat puskesmas ( nursalam dalam muhamad,2009 ). Perawat juga merupakan sumberdaya manusia dengan populasi terbanyak di puskesmas. Perawat berperan penting dalam menciptakan pandangan masyarakat terhadap pelayanan kesehatan kususnya perawaat pelaksana di ruang rawat inap. Perawat pelaksana di ruang rawat inap mempunyai uraian tugas yang lebih komplek perawat pelaksana di rung rawat inap memberikan pelayanan 24 jam dalam sehari sehingga memberi pengaruh yang sangat berarti terhadap mutu pelayanan puskesmas kepada masyarakat sebagai pemakai jasa di puskesmas ( kuswantoro, 2012 ).

Menurut Sedarmayanti (2009) motivasi dan lingkungan kerja yang baik akan mendorong pegawai agar senang bekerja dan meningkatkan rasa tanggung jawab untuk melakukan pekerjaan dengan lebih baik menuju kearah peningkatan kinerja perawat.

Berdasarkan hasil survei awal di Puskesmas Tapung dari 10 orang perawat yang mempunyai motivasi kerja kurang baik sebanyak 7 orang sering datang terlambat dan jarang mengikuti apel, dan lingkunan kerja yang kurang kondusif seperti kesalah pahaman antar rekan kerja, kurangnya fasilitas pendukung seperti tidak ada AC di dalm ruangan, tidak ada 
komputer di ruangan perawat dapat berdampak pada menurunnya kualitas pelayanan langsung kepada pasien yang dirawat di puskesmas Tapung, dan hal ini dapat kita dan yang saya amati satu tahun belakangan ini, terjadi penurunan kunjungan pasien yang yang terus terjadi setiap bulanya.

Motivasi kerja adalah dorongan atau kehendak yang mempengaruhi prilaku tenaga kerja untuk dapat meningkatkan kinerja. Lingkungan kerja adalah presepsi anggota organisasi secara individual maupun kelompok dan mereka yang secara tepat berhubung internal dengan organisasi. Menurut sudarmayanti ( 2009 ) lingkungan dan iklim kerja yang baik akan mendorong pegawai agar senang bekerja dan meningkatkan rasa tanggung jawab untuk melakukan pekerjaan dengan lebih baik menuju kearah peningkatan kinerja.

Berdasarkan hasil penelitian minarsih ( 2011 ) menunjukkan di rumah sakit pemerintah perawat pelaksana ruang rawat inap banyak yang kurang memperhatikan lingkungan kerja, sikap dan perhatian rendah terhadap pasien yang berakibat menurunya kinerja perawat (sedarmayanti, 2009 ). Akibat negatif dari banyaknya tugas tambahan perawat pelaksana puskesmas rawat inap diantaranya timbulnya emosi perawat yang tidak sesuai dengan yang diharapkan yang berdampak buruk bagi kinerja perawat pelaksana puskesmas Tapung. karena puskesmas Tapung menjadi puskesmas rujukan diwilayah kerja kecamatan Tapung yang memiliki 15 tempat tidur, 3 pelayanan dan 60 orang pegawai yang diantaranya 35 orang perawat. Tenaga perawat yang terdiri dari 30 orang perawat di ruang rawat inap dan 5 orang perawat poli rawat jalan.
Berdasarkan hasil wawancara dari 10 orang perawat pelaksana rawat inap yang mempunyai motivasi kurang sebanyak 7 orang dan lingkungan kerja yang kurang baik seperti sarana dan prasarana yang kurang mendukung sehingga kinerja perawat pelaksana rawat kurang baik, dan manajemen kurang baik dapat berdampak pada kinerja perwat Kepala tata usaha menyampaikan bahwa pencapaian kinerja perawat rawat inap yang dilakukan oleh perawat pelaksana rawat inap kurang dari $50 \%$.

Berdasarkan data sekunder pencapaian kinerja perawat di ruang rawat inap puskesmas Tapung kurang dari 50\% padahal standar kemenkes $70 \%$. Berdasarkan studi pendahuan yang dilakukan pada 10 keluarga pasien di ruang rawat inap. 8 di antaranya tidak puas terhadap kinerja perawat pelaksana di rung rawat inap dikarenakan sering terjadinya keterlambatan penangan penggantian cairan infus, kurangnya pencatatan register, yang ada di rung rawat inap puskesmas Tapung.

\section{TINJAUAN PUSTAKA}

Kinerja sebagai hasil-hasil fungsi pekerjaan /kegiatan seseorang atau kelompok dalam suatu oeganisasi yang dipengaruhi beberapa faktor untuk mencapai tujuan organisasi dalam periode waktu tertentu (pabandu, 2006). Sedangkan mangku negara (2009) kinerja (prestasi kerja)adalah hasil kerja secara kualitas dan kuantitas yang dicapai seseorang pegawai dalam melaksanakan tugasnya sesuai dengan tanggung jawab yang diberikan kepadanya. Menurut prawirosentono, kinerja atau performance adalah usaha yang dilakukan dari hasil kerja yang dapat dicapai seseorang atau sekelompok orang dalam organisasi 
sesuai dengan wewenang dan tanggung jawab masing masing dalam rangka mencapai tujuan organisasi bersangkutan secara legal, tidak melanggar hukum dan sesuai dengan moral maupun etika ( Usman, 2011 ).

Perawat sebagai salah satu tenaga kesehatan di puskesmas memegang peranan penting dalam upaya mencapai tujuan pembangunan kesehatan. Keberhasilan pelayanan kesehatan bergantung pada partisipasi perawat dalam meemberikan asuhan keperawatan yang berkualitas bagi pasien (potter dan perry, 2009).

1. Faktor yang berhubungan dengan kinerja perawat baik yang berhubungan dengan tenaga kerja maupun lingkungan organisasi.

Menurut ( sedarmayanti, 2011 ) faktor yang berhubungan dengan kinerja adalah :

a. Motivasi

Motivasi dapat diartikan sebagai kekuatan (energi) seseorang yang dapat menimbulkan tingkat persistensi dan entusiasmenya dalam melaksanakan suatu kegiatan, baik yang bersumber dari dalam diri individu itu sendiri (motivasi intrinsik) maupun dari luar individu (motivasi ekstrinsik). Seberapa kuat motivasi yang dimiliki individu akan banyak menentukan kualitas prilaku yang ditampilkanya, baik dalam konteks belajar, bekerja, maupun dalam kehidupan lainya.

Motivasi dapat diartikan sebagai suatu daya pendorong (drifing force) yang menyebabkan orang berbuat sesuatu atau yang diperbuat karena takut akan sesuatu. Menurut mulianto (2006 ) motivasi kerja adalah dorongan kehendak yang mempengaruhi prilaku tenaga kerja untuk dapat meningkatkan kinerja karna ada keyakinan bahwa peningkatan kinerja mempunyai manfaat untuk dirinnya. Motivasi rendah ditimbulkan oleh berbagai sebab yang berakibat pada rendahnya kinerja. Menurut hasibuan (2010) dimana dikatakan bahwa motivasi sangat penting karena dengan motivasi diharapkan setiap individu pegawai dapat membangkitkan keinginan untuk bekerja keras dan antusias untuk mencapai kinerja yang tingi. Setiap orang memiliki motivasi dalam hidup yang dapat dijadikan suatu alasan pendorong untuk bekerja lebih keras lagi untuk menghasikan output secara maksimal.

Menurut hakim (2009) indikator penilaian motivasi kerja adalah :

1) Pencapaian prestasi kerja menjadi indikator yang penting karena dengan pencapaian prestasi kerja pegawai dapat mengukur kemampuan kerja yang mereka lakukan.

2) Pengakuan hasil kerja Menurut suroso dalam maharlin ( 2013 ) salah satu faktor yang 


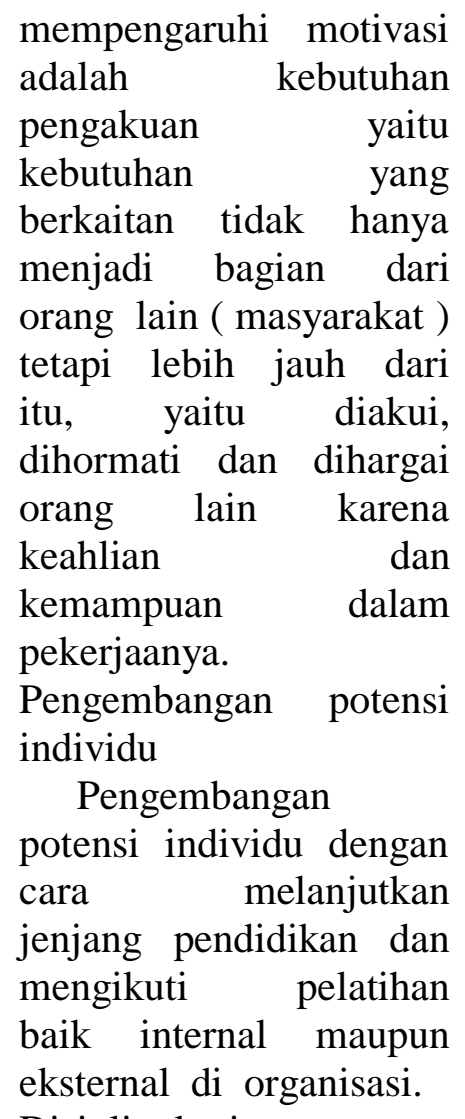

4) Disiplin kerja

Disiplin kerja dapat diartikan sebagai sikap menghargai, patuh,, dan taat, terhadap peraturan dan tata tertib yang berlaku ditempat kerja.

5) Etika kerja

Sikap dan etika
kerja yang saling
menghormati $\begin{array}{r}\text { antar } \\ \text { pegawai memberikan } \\ \text { nilai plus dan membuat } \\ \text { pegawai yang lain } \\ \text { menjadi betah untuk } \\ \text { bekerja dan nyaman } \\ \text { karena mendapat respon } \\ \text { yang baik }\end{array}$

b. Lingkungan kerja

Menurut wirawan ( 2007 ) lingkungan kerja adalah presepsi anggota organisasi ( secara individual maupun kelompok ), dan mereka

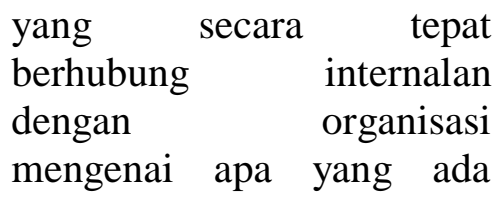
atau terjadi dilingkungan internal organisasi secara rutin yang mempengaruhi sikap dan prilaku organisasi dan kinerja anggota organisasi yang kemudian menentukan kinerja organisasi.

Lingkungan dan iklim kerja yang baik akan mendorong pegawaiagar senang bekerja dan meningkatkan rasa tanggung jawab untuk melakukan pekerjaan dengan lebih baik menuju kearah peningkatan kinerja. Berdasarkan teori pengharapan kondisi kerja fisik yang sesuai dan nyaman dan peralatan alat kerja, informasi dan suberdaya lain yang cukup akan mempunyai pengaruh yang positif terhadap usaha pegawai dalam suatu organisasi (www.gdl.itb.ac.id dalam andina pertiwi 2010 ).

c. Pendidikan

Pada umumnya orang yang memeiliki pendidikan yang lebih tinggi akan mempunyai wawasan yang lebih luas terutama penghayatan akan artinya pentingnya kinerja. Pendidikan disini dapat berarti pendidikan formal maupun non formal. Tingginya kesadaran akan produktivitas dapat mendorong pegawai yang bersangkutan melakukan 


\author{
tindakan \\ meningkatkan kinerja. \\ d. Keterampilan \\ Pada aspek tertentu \\ apabila pegawai semakin \\ termpil maka akan lebih \\ mampu bekerja serta \\ menggunakan fasilitas kerja \\ dengan baik. Pegawai akan \\ menjadi lebih terampil \\ apabila mempunyai \\ kecakapan yang cukup serta \\ memiliki kesempatan \\ berprestasi di organisasi. \\ Indikator ketrampilan \\ adalah pengalaman kerja \\ dan kesempatan berprestasi \\ (Sedarmayanti, 2011)
}

Sikap mental terdiri dari tiga macam yaitu motivasi, disiplin kerja dan etika kerja. Sikap mental yang kuat akan menghasilkan kinerja yang optimal. Pendidikan yang tinggi akan menghasilkan wawasan yang luas tentang arti pentingnya kinerja sehingga tercipta tindakan yang meningkatkan kinerja. Tingkat penghasilan yang memedai akan meningkatkan konsentrasi kerja dan meningkatkan kinerja. Lingkungan kerja yang baik akan membuat pegawai senang bekerja dan e. Kesempatan berprestasi Pegawai yang bekerja tentu mengharapkan peningkatan karier atau pengembangan potensi pribadi yang nantinya akan bermanfaat bagi dirinya maupun organisasi. Apabila terbuka kesempatan untuk berprestasi, maka akan menimbulkan dorongan psikologis untuk meningkatkan dedikasi serta pemanfaatan potensi yang dimiliki untuk meningkatkan produktivitas kerja (Sedarmayanti, 2009) meningkatkan kinerja. Dan kesempatan berprestasi akan meningkatkan dedikasi pemanfatan potensi sehingga meningkatkan kinerja. Sehingga sikap mental, pendidikan, tingkat penghasilan, lingkungan kerja, dan kesempatan berprestasi merupakan faktor yang berhubungan dengan kinerja.

A. Kerangka Konsep

Dalam membuat kerangka konsep peneliti tidak menggunakan seluruh variabel yang terdapat pada kerang kateori. Peneliti hanya 


\begin{abstract}
memilih beberapa variable disesuaikan dengan tujuan penelitian serta beberapa pertimbangan lain yang digunakan oleh peneliti.

Variabel sikap mental mencakup motivasi disiplin kerja dan etika kerja. Disiplin kerja tidak diteliti dalam penelitian ini karena indicator disiplin kerja sama dengan salah satu indicator kinerja perawat yaitu pencapaian organisasi, etika kerja tidak diteliti dalam penelitian ini karna indicator etika sama dengan salah satu indicator lingkungan kerja yaitu kerja sama dalam melaksanakan tugas dan hubungan antara rekan kerja. Variabel ketrampilan tidak diteliti oleh peneliti karena objek yang diteliti hanya perawat pelaksana yang memuliakan tugas dan keterampilan yang sama sehingga data bersifat homogen.
\end{abstract}

Dengan demikian

disusunlah kerangka konsep guna menganalisis hubungan motivasi dengan kinerja perawat pelaksana rawat inap di puskesmas perawatan Tapung.

Penelitian ini akan mencari hubungan antara variable independen (motiovasi) terhadap variable dependen (kinerja perawat).

\section{HASIL PENELITIAN}

Penelitian yang dilakukan pada tanggal 25 juli sampai 5 agustus 2016 terhadap 30 responden di UPTD Kesehatan Tapung dengan judul " Hubungan Motivasi dengan Kinerja Perawat Pelaksana Rawat Inap di UPTD Kesehatan Tapung Tahun 2016". Dari hasil penyebaran kuisioner di dapatkan hasil sebagai berikut:

Analisa Univariat

Analisis univariat dilakukan untuk mendapatkan gambaran mengenai karakteristik responden meliputi ( umur, jenis kelamin, pendidikan ), hasil analisa univariat yang diperoleh pada penelitian ini adalah sebagai berikut:

1. Karakteristik Responden Berdasarkan pengumpulan data melalui penyebaran kuisioner terhadap 30 responden di UPTD Kesehatan Tapung di dapatkan karakteristik responden berdasarkan kelompok umur, jenis kelamin, pendidikan, pada tabel sebagai berikut.

Tabel 4.1 Distribusi frekuensi responden berdasarkan Usia Perawat Pelaksana Di UPTD Kesehatan Tapung Kab. Kampar Tahun 2018.

\begin{tabular}{cccc}
\hline No & Usia & Frekuensi & Persen \% \\
\hline 1 & $25-35$ tahun & 19 & 63,3 \\
2 & $36-45$ tahun & 11 & 36,7 \\
\hline & Total & $\mathbf{3 0}$ & $\mathbf{1 0 0}$ \\
\hline
\end{tabular}

Sumber: dari kuisioner penelitian 
Dari 30 orang responden

25-35 tahun sebanyak 19

yang paling banyak berusia

orang $(63,3 \%)$,

Tabel 4.2 Distribusi frekuensi responden berdasarkan pendidikan Perawat Di UPTD Kesehatan Tapung Kab. Kampar Tahun 2018.

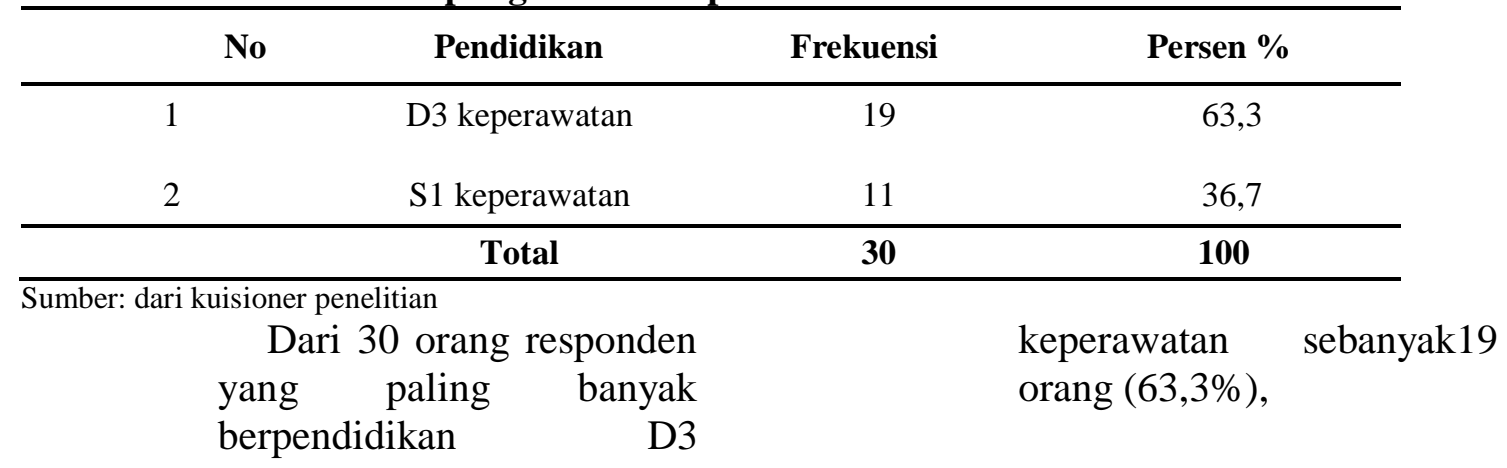

Tabel 4.3 Distribusi frekuensi responden berdasarkan Jenis Kelamin Perawat Di UPTD Kesehatan Tapung Kab. Kampar Tahun 2018.

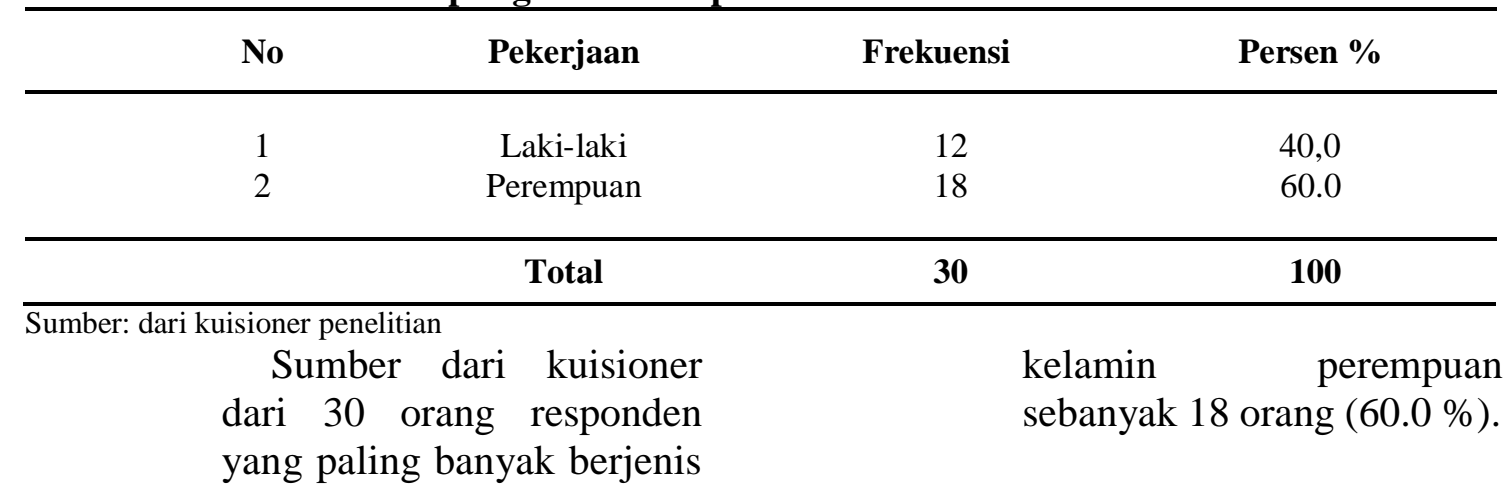

Tabel 4.4 Distribusi frekuensi berdasarkan motivasi kerja Perawat Di UPTD Kesehatan Tapung Kab. Kampar Tahun 2018.

\begin{tabular}{|c|c|c|c|}
\hline No & Motivasi kerja & Frekuensi & Persen \% \\
\hline 1 & Termotivasi & 18 & 60.0 \\
\hline 2 & Tidak termotivasi & 12 & 40.0 \\
\hline & Total & 30 & 100 \\
\hline
\end{tabular}

Sumber: dari kuisioner penelitian

Sumber dari kuisioner kerja tinggi sebanyak 18 Dari 30 orang responden orang $(60.0 \%)$.

yang memiliki motivasi

Tabel 4.5 Distribusi frekuensi berdasarkan kinerja Perawat Pelaksana Di UPTD Kesehatan Tapung Kab. Kampar Tahun 2018.

\begin{tabular}{llll}
\hline No & Kinerja perawat & Frekuensi & Persen \% \\
\hline
\end{tabular}




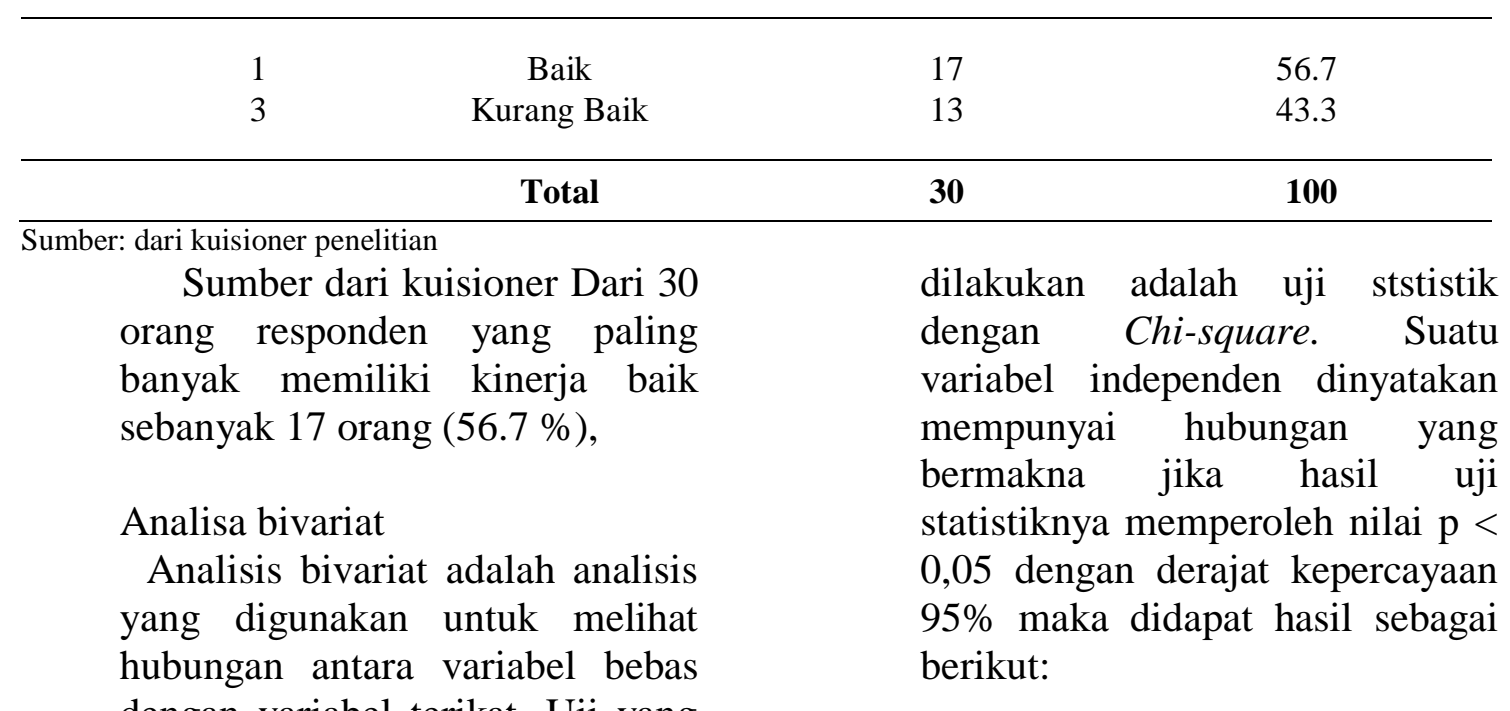

Tabel 4.6 Tabel silang berdasarkan hubungan Motivasi Dengan Kinerja Perawat Pelaksana Di UPTD Kesehatan Tapung Kab. Kampar Tahun 2018.

\begin{tabular}{|c|c|c|c|c|c|c|c|c|}
\hline \multirow{3}{*}{ Motivasi } & \multicolumn{4}{|c|}{ Kinerja perawat } & \multicolumn{2}{|c|}{ Total } & \multirow[t]{3}{*}{$\begin{array}{c}\mathbf{P} \\
\text { value }\end{array}$} & \multirow[t]{3}{*}{ POR } \\
\hline & \multicolumn{2}{|c|}{ Baik } & \multicolumn{2}{|c|}{ Kurang baik } & & & & \\
\hline & $\mathbf{N}$ & $\%$ & $\mathbf{N}$ & $\%$ & $\mathbf{N}$ & $\%$ & & \\
\hline Termotivasi & 14 & 77.8 & 4 & 22.2 & 18 & 100 & & \\
\hline Tidak termotivasi & 3 & 25 & 9 & 75 & 12 & 100 & 0,004 & 10.50 \\
\hline Total & 17 & 56,7 & 13 & 43,3 & 30 & 100 & & \\
\hline
\end{tabular}

Sumber: dari kuisioner penelitian

Dari Tabel diatas menunjukan bahwa dari 18 perawat dengan persentasi $(60.0 \%)$ yang mempunyai motivasi kerjanya termotivasi terdapat 4 orang perawat dengan persentasi (22.2\%) dengan kinerja kurang baik. Sedangkan dari 12 perawat dengan persentasi $(40,0 \%)$ yang mempunyai motivasi tidak termotivasi terdapat 3 orang perawat yang mempunyai kinerja baik, secara stastistik ada hubungan antara motivasi dengan kinerja perawat pelaksana rawat inap di UPTD Kesehatan Tapung Kecamatan Tapung Kabupaten Kampar dengan nilai $\mathrm{p}=$ 0,004 dan POR $=10.50$ motivasi perawat yang tidak termotivasi berpeluang 10.50 kali lebih cenderung untuk tidak punya kinerja baik dibandingkan dengan perawat yang mempunyai motivasi termotivasi.
Dari hasil analisis diatas menunjukkan nilai $\mathrm{P}$-value $=0.004$ dengan $\alpha=0.05$. jika $\mathrm{P}$-value $>\alpha$ maka $\mathrm{HO}$ diterima dan Ha ditolak. 0.004< 0.05 (P-value $<\alpha$ ) maka Ha diterima dan H0 ditolak.

Hasil analisis diatas dapat menjawab hipotesis penelitian.Dimana hipotesis penelitian ini adalah ada Hubungan Motivasi Dengan Kinerja Perawat Pelaksana Di UPTD Kesehatan Tapung Kab.Kampar Tahun 2016.

\section{PEMBAHASAN}

Pembahasan Penelitian

Analisa bivarat

Hubungan motivasi dengan kinerja perawat pelaksana rawat inap di UPTD Kesehatan Tapung Tahun 2016 
Berdasarkan hasil penelitian, maka peneliti membahas tentang Hubungan Motivasi Denngan Kinerja Perawat Pelaksana Rawat Inap di UPTD Kesehatan Tapung Kecamatan Tapung Kabupaten Kampar Tahun 2018. sesuai kuisioner yang telah disebarkan dan fakta fakta yang peneliti dapatkan.

Berdasarkan hasil penelitian yang dilakukan pada 30 responden yang berada di UPTD Kesehatan Tapung Kecamatan Tapung Kabupaten Kampar. Bahwa perawat yang punya motivasi termotivasi dengan kinerja baik sebanyak (77.8\%) dan terdapat 4 orang (22.2\%), responden yang punya kinerja kurang baik, dan perawat yang mempunyai motivasi tidak termotivasi sebanyak (75.0\%) dan terdapat perawat yang punya kinerja baik sebanyak (25.0\%).

Dari hasil uji statistik didapatkan nilai $\mathrm{p}=0,004$ dan $\mathrm{POR}=10.50$ hal ini menunjukkan ada hubungan antara motivasi dengan kinerja perawat pelaksana rawat inap dimana perawat yang mempunyai motivasi rendah 10.50 kali lebih cenderung punya kinerja kuranng baik.

Hasil analisis diatas dapat menjawab hipotesis penelitian. Dimana hipotesis penelitian ini adalah ada Hubungan Motivasi Dengan Kinerja Perawat Pelaksana Di UPTD Kesehatan Tapung Kab.Kampar Tahun 2018.

Motivasi dapat diartikan sebagai kekuatan (energi) seseorang yang dapat menimbulkan tingkat persistensi dan entusiasmenya dalam melaksanakan suatu kegiatan, baik yang bersumber dari dalam diri individu itu sendiri (motivasi intrinsik) maupun dari luar individu (motivasi ekstrinsik). Seberapa kuat motivasi yang dimiliki individu akan banyak menentukan kualitas prilaku yang ditampilkanya, baik dalam konteks belajar, bekerja, maupun dalam kehidupan lainya.

Motivasi dapat diartikan sebagai suatu daya pendorong (drifing force) yang menyebabkan orang berbuat sesuatu atau yang diperbuat karena takut akan sesuatu. Menurut mulianto ( 2006 ) motivasi kerja adalah dorongan kehendak yang mempengaruhi prilaku tenaga kerja untuk dapat meningkatkan kinerja karna ada keyakinan bahwa peningkatan kinerja mempunyai manfaat untuk dirinnya. Motivasi rendah ditimbulkan oleh berbagai sebab yang berakibat pada rendahnya kinerja. Menurut hasibuan (2010 ) dimana dikatakan bahwa motivasi sangat penting karena dengan motivasi diharapkan setiap individu pegawai dapat membangkitkan keinginan untuk bekerja keras dan antusias untuk mencapai kinerja yang tingi. Setiap orang memiliki motivasi dalam hidup yang dapat dijadikan suatu alasan pendorong untuk bekerja lebih keras lagi untuk menghasikan output secara maksimal.

Berdasarkan uraian diatas peneliti berasumsi bahwa, 
hubungan motivasi dengan kinerja perawat pelaksana rawat inap terdapat sangat erat kaitanya. Dari 18 orang dengan persentasi $(60,0 \%)$ perawat yang mempunyai motivasi termotivasi terdapat 4 orang perawat dengan persentasi $(22.2 \%)$ yang punya kinerja kurang baik, berdasarkan wawancara dengan 4 orang responden hal ini disebabkan karena kurangnya kesadaran perawat untuk bekerja dengan baik dan juga kurang adanya riwod bagi perawat yang berprestasi. Sedangkan dari 12 orang perawat dengan persentasi $(40,0 \%)$ yang tidak termotivasi terdapat 3 orang perawat dengan persentasi $(25.0 \%)$ yang punya kinerja baik. Berdasarkan hasil wawancara dari 3 orang perawat hal ini dipengaruhi karena perawat mengiuti peraturan dimana tempat mereka bekerja, karena perawat takut mendapat teguran dan sangsi dari atasan.

\section{Kesimpulan}

Bagi UPTD Kesehatan Tapung

Saran dan kritikan yang dapat berguna bagi menejemen puskesmas sebagai bahan pertimbangan dalm rangka pembangunan puskesmas rawat inap untuk meningkatkan kinerja perawat sehingga terciptanya pelayanan puskesmas yang bermutu. Informasi yang didapat oleh puskesmas adalah mengetahui hubungan motivasi dengan kinerja perawat pelaksana diruang rawat inap puskesmas Tapung.

\section{Saran}

Dapat memacu penelitianpenelitian lebih lanjut tentang hubungan motivasi dengan kinerja perawat pelaksana rawat inap di puskesmas Tapung.

\section{DAFTAR PUSTAKA}

Andina

pratiwi, (2010).

www.gdl.itb.ac.id organisasi dan motivasi di akses tanggal 29 maret 2016

Depkes RI, (2007). Sistim Kesehatan Nasional, Jakarta

Depkes RI, (1998). Sistim perumah sakitan, Manajemen Rumasakit Sakit, Jakarta

Dr. Nursalam, M.Nurs, Hons, (2012). Manajemen Keperawatan edisi ketiga, Salemba Medika, Jakarta

Hasibuan, (2010). Organisasi dan Motivasi, PT. Bumi Aksara, Jakarta

Irham Fahmi, SE, M.Si, (2014). Manajemen produksi dan oprasi, Penerbit Alfabeta, cetakan pertama, Bandung

Kuswantoro Putra, (2012). Pengaruh mutu pelayanan keperawatan terhadap kepuasan pasien, di ruang rawat inap rumah sakit islam, Malang

Lukman Hakim, (2009). Faktor faktor yang berhumungan dengan produktivitas kerja karyawan, di dinas kesehatan kabupaten tabalong, Kalimantan Selatan

Minarsih, (2011). Hubungan lingkungan kerja perawat dengan produktivitas kerja perawat di RSUD, DR.M. Jamil padang, Universitas Andalas

Mulianto sindu, (2006). Supervisi di perkaya prespektif syariah, PT. Eelex Media Komputindo, Jakarta

Prof, Dr. H.A.R, Tailar, M.sc, Ed, (2009). Membenahi Pendidikan Nasional. Penerbit Renika Cipta, Jakarta 
70 | HUBUNGAN MOTIVASI DENGAN KINERJA PERAWAT PELAKSANA DI UPTD KESEHATAN TAPUNG KAB. KAMPAR TAHUN 2018

Suyanto, SKP, M.Kep, (2009). Mengenal kepemimpinan dan manajemen Keperawatan di Rumah Sakit. Penerbit Mitra Cendika, Cetakan ke tiga, Jakarta Sedarmayanti, (2009). Sumber daya manusia dan produktivitas kerja. Penerbit Mandar Maju, Cetakan pertama, Bandung

Sedarmayanti, (2011). Sumber daya manusia dan produktivitas kerja. Penerbit Mandar Maju, Cetakan kedua, Bandung

Sugiono, (2009). Metode penelitian bisnis. CV. Alfabeta, Cetakan kesebelas, Bandung 